\title{
INFLUENCE OF ORGANIC AMEND- MENT AND INORGANIC SOURCES IN RELATION TO CROP YIELD OF RAGI AND SOIL CHARACTERISTICS
}

\author{
*Gopal Dasar **G.N. Gajanana, ***Basavarai
}

\begin{abstract}
A field experiment was conducted on a sandy clay loam soil during summer season to characterize the soil crust and to alleviate soil crust with organic waste and other amendments to improve the yield. Maize residue treatment recorded significantly higher grain and strow yield, seedling emergence, reduction in the crust strength and increase in the moisture content of crust was observed due to maize residue incorporation. Soil crust contains higher amount of finer fractions, sesquioxides, iron, dispersion ratio and lower amount of organic matter The problem of soils crusting is common in agricultural soils under a
\end{abstract}

\footnotetext{
* Assistant Professor of Soil Science and Agricultural Chemistry, University of Agricultural Sciences, College of Forestry, Sirsi.

** Associate Professor of Soil Science and Agricultural Chemistry, University of Agricultural Sciences, G.K.V.K., Bangaiore-65.

*** University of Agriculturol Sciences. Dhanwad-8.
} 
wide range of climate conditions. Soil crust is a hard layer formed on the surface due to impact of rain drops and subsequent drying. Though the seeds germinate below the crust, seedlings are not able to exert sufficient upward pressure to pierce through the crust resulting in preemergence death of seedlings, crusts are known to adversely affect seedling emergence, early growth of seedling oxygen supply, moisture iniliferation but increase erosin and run off.

A good crop stand is a pre-requisite for higher production which depends on proper germination and emergence. During Kharif season soil crusting poses serious problem to seedling emergence in alfisol of dry land areas.

Investigations carried out so for on the development of hard soil crust, have largely attributed this phenomena to soil dispersion and deteriorated soil structure, rainfall intensity and wetting and drying cycles. Soil crusts are characterized with greater mechanical strength, low porosity, high bulk density, low degree of aggregation, high amount of silt and clay, higher amount of sesquiaxides and lower amount of organic matter. Crust formation in cultivated soil is not a desirale phenomena from the point of crop emergence, growth and other soil characteristics.

The role of organic substances in alleviating soil crust formation has not been studied adequately with a view for higher production. Hence, the study was initiated.

\section{Materials and Method}

The experiment was laidout in a randomized complete block design at Gandhi krishi Vigana Kendra, Bangalore with four replications and seven treatments, the plot size was $1.8 \times 2.0 \mathrm{~m}$. Calculated quantity of seeds were sown in rows of $30 \mathrm{~cm}$ distance from row to row and $10 \mathrm{~cm}$ between seed to seed. PR-202 variety of ragi seeds were used in the experiment. The soil crust was developed artificially by adding water to simulate $20 \mathrm{~mm}$ of rainfall. Immediately after sowing irrigation water was applied using rose can at a height of four feet in such away that it simulated the natural rainfall. The quantity of water added was equal to $20 \mathrm{~mm}$ of rainfall in case of all the plots. The residues were incorporated in the soil is moist conditions and were allowed to decompose for 21 days. Potassium chloride (T6) was applied at the time of sowing after gap of 21 days sowing was done at the rate of $10 \mathrm{~kg} / \mathrm{ha}$ at the time of sowing 50 per cent $\mathrm{N}$ as urea, the entire $\mathrm{P}_{2} \mathrm{O}_{5}$ as super phosphate and entire $\mathrm{K}_{2} \mathrm{O}$ as muriate of potash were applied (50:50:25 kg/ha) The remaining half of the nitrogen was applied 40 days after sowing the crust strength, per cent moisture content and seedling emergence were recorded on $5^{\text {th }}$ $8^{\text {th }}, 12^{\text {th }}$ day. After twelve days of observation the plots were irrigated once in every 
8 days interval by flooding. After the crust strength measurement, samples of the soil crust and soil below crust were collected on $5^{\text {th }}, 8^{\text {th }}$ and $12^{\text {th }}$ day alter sowing were pooled and analysed as per the standard method of analysis.

\section{Results and Discussion}

\section{Seedling emergence or ragi in different treatments}

The data indicates significant variation in the emergence of seedling due to different treatments. The seedling emergence was maximum in maize residue treated plots and all the treatments were significantly superior to control. The seedling emergence was better because of the favourable moisture status and low crust strength. AS shown in the (Table 1) higher moisture content and low crust strength may be responsible for better germination. Ranganatha (1976) reported higher seedling emergence of ragi in FYM treatment and attributed it to increased moisture content reduction in crust strength and bulk density. Similarly many workers observed reduction in soil crust due to organic matter application (Parvathappa ef al. 1988).

Table I Seedling emergence of ragi as Influenced by different treatments to alleviate soil crust

\begin{tabular}{|l|l|l|l|}
\hline \multicolumn{1}{|c|}{ Treatments } & \multicolumn{3}{|c|}{ Number of seedlings emerged per plot } \\
\hline & 5 DAS & 8 DAS & 12 DAS \\
\hline T1FYM & 83.00 & 106.00 & 105.00 \\
\hline T2 Maize residue & 109.00 & 115.00 & 116.00 \\
\hline T3 Coir pith & 75.00 & 77.00 & 78.00 \\
\hline T4Groundnuthusk & 79.00 & 82.00 & 82.00 \\
\hline T5 Press mud & 89.00 & 94.00 & 94.00 \\
\hline T6 Potassium & 83.00 & 88.00 & 88.00 \\
\hline T7 Control & 61.00 & 66.00 & 66.00 \\
\hline F Test & $*$ & & $*$ \\
\hline CD at 6\% & 3.10 & 2.50 & 2.58 \\
\hline
\end{tabular}

DAS : Days after sowing 


\section{Soil crust strengh and moisture content}

There, was significant variation in the crust strength and moisture content (Table II) of soil crust due to different treatments. Maize residue reduced the crust strength significantly than all the other treatments except addition of potassium. All the organic amendments significantly reduced the crust strength. Baver ef ol (1972) reported that organic matter application will reduce crusting by improving infilteration, air exchange and formation of stable soil aggregates which resist dispersion. The present study reveals that application of organic resides was helpful in reducing soil crust strength. Similar observations were also reported by Hazra (1986) and Gupta et al (1987). In the present study all the organic matter sources have increased the moisture content because of which crust strength was also reduced.

Table II. Crust Strength and its Moisture Content

\begin{tabular}{|c|c|c|c|c|c|c|}
\hline \multirow[t]{2}{*}{ Treatments } & \multicolumn{3}{|c|}{ Crust strength $\left(\mathrm{kg} / \mathrm{cm}^{2}\right)$} & \multicolumn{3}{|c|}{ Moisture content (\%) } \\
\hline & 5 DAS & 8DAS & 12 DAS & $5 \mathrm{DAS}$ & 8DAS & $12 \mathrm{DAS}$ \\
\hline TI FYM & 2.34 & 2.57 & 2.98 & 7.43 & 7.58 & 4.48 \\
\hline $\begin{array}{l}\text { T2 Maize } \\
\text { residue }\end{array}$ & 2.09 & 2.09 & 2.62 & 8.40 & 8.66 & 7.41 \\
\hline T3 Coir pith & 2.69 & 2.74 & 3.27 & 6.29 & 6.66 & 4.03 \\
\hline $\begin{array}{l}\text { T4 Groundnut } \\
\text { husk }\end{array}$ & 2.46 & 2.54 & 2.92 & 6.40 & 6.66 & 4.66 \\
\hline T5 Pressmud & 2.41 & 2.60 & 2.79 & 6.98 & 7.20 & 4.72 \\
\hline T6 Potassium & 2.26 & 2.67 & 2.76 & 5.01 & 5.57 & 4.82 \\
\hline T7 Control & .3 .18 & 3.52 & 4.00 & 4.24 & 4.87 & 3.58 \\
\hline F test & * & ${ }^{*}$ & $*$ & * & & $*$ \\
\hline CD at $6 \%$ & 0.21 & 0.27 & 0.23 & 0.62 & 0.34 & 0.22 \\
\hline
\end{tabular}

DAS : Days after sowing

\section{Grain and straw yield of ragi}

Favourable conditions for germination and seedling emergence are important factors for good crop stand, which is a pre-requisite for better yield. The hard and compact layer will hamper the emergence of seedling thus reducing the yield of crops. 
A significant increase in the grain and straw yield of ragi over control was observed in all the treatments (Fig. 1). The data in Table Ill indicates that reduction in the seedling emergence was one of the factor for variation in yield. Hazra (1986) reported a significantly higher forage yield of pearl millet than control due to addition of organic residues like ground nut husk, FYM, bajra stalk and dry grass.

Table III. Influence of alleviation of soil crust on grain and straw yield of ragi

\begin{tabular}{|l|c|c|}
\hline \multicolumn{1}{|c|}{ Treatments } & Grain yield $(\mathrm{kg} / \mathrm{ha})$ & Straw yield $(\mathrm{kg} / \mathrm{ha})$ \\
\hline T1 FYM & 2189.10 & 4199.70 \\
\hline T2 Maize residue & 2847.60 & 6647.60 \\
\hline T3 Coir pith & 1456.00 & 3042.30 \\
\hline T4 Groundnut husk & 1878.30 & 4365.00 \\
\hline T5 Pressmud & 2236.40 & 4663.40 \\
\hline T6 Potassium & 1640.20 & 4794.90 \\
\hline T7 Control & 664.70 & 2876.90 \\
\hline F test & $*$ & $*$ \\
\hline CD at $6 \%$ & 234.5 & 1208.90 \\
\hline
\end{tabular}

The variation in yield can be attributed to variation in crust strength and its effect on moisture status, seedling emergence, and their rot growth. The findings are well backed by the findings of Unger and McCalla (1980) and Singh and Chaudhary (1985).

\section{Mechanical Composition of soil crust and soil below crust.}

The effect of various mechanical composition of the soil crust are presented in Table N. The data indicate that soil crust have lower amount of coarse and fine sand than soil below crust. The silt and clay content are higher in soil crust than soil below the crust. Earlier studies indicates that soil crusts have more finer particles than soil below the crust (Ranganatha, 1976). The variations in different treatments can be attributed to the exposure to dispersion and compaction. Finer soil particles are susceptible for dispersion and when dried, hard on the surface resulting in a tough surface layer (Zaslavasky et af 1980) 
Table IV. Mechanical composition of soil crust and soil below it

\begin{tabular}{|l|c|c|c|c|c|c|c|c|}
\hline Treatments & \multicolumn{2}{c|}{$\begin{array}{c}\text { Coarse sand } \\
(\%)\end{array}$} & \multicolumn{2}{c|}{$\begin{array}{c}\text { Fine sand } \\
\text { (\%) }\end{array}$} & \multicolumn{2}{c|}{$\begin{array}{c}\text { Silt } \\
(\%)\end{array}$} & \multicolumn{2}{c|}{$\begin{array}{c}\text { Clay } \\
(\%)\end{array}$} \\
\hline & $\begin{array}{c}\text { Soil } \\
\text { crust }\end{array}$ & $\begin{array}{c}\text { Soil } \\
\text { below } \\
\text { crust }\end{array}$ & $\begin{array}{c}\text { Soil } \\
\text { crust }\end{array}$ & $\begin{array}{c}\text { Soil } \\
\text { below } \\
\text { crust }\end{array}$ & $\begin{array}{c}\text { Soil } \\
\text { crust }\end{array}$ & $\begin{array}{c}\text { Soil } \\
\text { below } \\
\text { crust }\end{array}$ & $\begin{array}{c}\text { Soil } \\
\text { crust }\end{array}$ & $\begin{array}{c}\text { Soil } \\
\text { below } \\
\text { crust }\end{array}$ \\
\hline TI FYM & 37.36 & 38.60 & 31.70 & 34.85 & 9.80 & 8.66 & 20.66 & 17.86 \\
\hline T2Maize residue & 37.60 & 36.92 & 32.82 & 34.20 & 8.30 & 7.15 & 21.20 & 21.60 \\
\hline T3 coirpith & 39.40 & 39.25 & 28.87 & 31.27 & 9.46 & 8.45 & 21.97 & 21.00 \\
\hline T4Groundnuthusk & 35.35 & 39.17 & 32.43 & 32.32 & 9.77 & 8.10 & 22.17 & 20.27 \\
\hline T5 Pressmud & 35.00 & 39.22 & 34.30 & 30.37 & 8.80 & 7.62 & 22.55 & 22.57 \\
\hline T6Potassium & 34.65 & 39.1 & 33.40 & 32.41 & 8.60 & 7.65 & 22.80 & 20.66 \\
\hline T7Control & 34.18 & 37.66 & 33.28 & 32.42 & 9.66 & 8.82 & 22.88 & 20.22 \\
\hline Ftest & $*$ & $*$ & $*$ & NS & $*$ & $*$ & $*$ & $*$ \\
\hline CD at6\% & 0.96 & 1.00 & 1.12 & $\%$ & 0.22 & 0.20 & 0.96 & 1.74 \\
\hline
\end{tabular}

\section{Organic matter and major nutrient status or soil crust and soil below crust}

The organic matter status (Table V) of soil crust was less than the soil below the crust. However the variation was not very distinct. There was significant variation in organic matter content of the soil in all the treatments except potassium and pressmud. It can be attributed to the orgnic nature of organic substance that are applied. Addition of organic wastes significantly increased the organic matter content of soil (Pandey et al., 1985).

The available nitrogen content (Table V) was marginally lower in soil crust than soil below the crust marked variation in the nitrogen content was observed among the treatments studied. The increase in nitrogen content in the samples where organic residues were applied in addition to fertilizers can be attributed to nitrogen release from residues to the available nitrogen pool. Similar obsenvation was also reported by Pandey et al. (1985).

The available phosphrous status Table $V$ varied significantly in soil crust and soil below the crust. Organic residues increased the available phosphorus significantly over control. There was no significant variation between control and potash application treatment. The increase in the available phosphorus due to organic 
Table V Organic matter and major nutrient status of soil crust and soil below it

\begin{tabular}{|c|c|c|c|c|c|c|c|c|}
\hline \multirow[t]{2}{*}{ Treatments } & \multicolumn{2}{|c|}{$\begin{array}{c}\text { Organic } \\
\text { matter }(\%)\end{array}$} & \multicolumn{2}{|c|}{$\begin{array}{l}\text { Available Nitro- } \\
\text { gen }\left(\mathrm{kg} \mathrm{h} \mathbf{a}^{-1}\right)\end{array}$} & \multicolumn{2}{|c|}{$\begin{array}{c}\text { Available } \\
\mathrm{P}_{2} \mathrm{O}_{5}\left(\mathrm{kgha}^{-1}\right)\end{array}$} & \multicolumn{2}{|c|}{$\begin{array}{c}\text { Available } \mathrm{K}_{2} \mathrm{O} \\
\left(\mathrm{Kg} \mathrm{ha} \mathrm{a}^{-1}\right)\end{array}$} \\
\hline & $\begin{array}{l}\text { Soil } \\
\text { crust }\end{array}$ & $\begin{array}{l}\text { Soil } \\
\text { below } \\
\text { crust }\end{array}$ & \begin{tabular}{|c|} 
Soil \\
crust
\end{tabular} & $\begin{array}{c}\text { Soil } \\
\text { below } \\
\text { crust }\end{array}$ & $\begin{array}{l}\text { Soil } \\
\text { crust }\end{array}$ & $\begin{array}{c}\text { Soil } \\
\text { below } \\
\text { crust }\end{array}$ & \begin{tabular}{|c|} 
Soil \\
crust
\end{tabular} & $\begin{array}{c}\text { Soil } \\
\text { below } \\
\text { crust }\end{array}$ \\
\hline TIFYM & 1.18 & 1.25 & 211.68 & 215.60 & 88.53 & 90.66 & 216.47 & 219.59 \\
\hline T2Maize residue & 1.25 & 1.30 & 227.36 & 239.12 & 91.69 & 92.89 & 213.75 & 218.90 \\
\hline T3Coirpith & 0.92 & 0.98 & $\mid 184.24$ & 199.92 & 88.12 & 88.44 & 213.88 & 218.56 \\
\hline T4Groundnuthusk & 1.03 & 1.10 & 199.92 & 211.68 & 93.34 & 90.66 & 209.62 & 210.991 \\
\hline T5Pressmud & 0.92 & 0.97 & 184,24 & 196.00 & 8.12 & 88.56 & 208.64 & 211.04 \\
\hline T6Potassium & 0.86 & 0.89 & 166.80 & 164.24 & 82.96 & 83.38 & 226.43 & .229 .60 \\
\hline T7Control & 0.85 & 0.89 & 166.80 & 172.14 & 82.96 & 83.38 & 210.69 & 210.66 \\
\hline Flest & * & $*$ & $*$ & * & * & * & * & * \\
\hline $\mathrm{CD}$ at $5 \%$ & 0.07 & 0.09 & 20.01 & 21.05 & 2.34 & 2.31 & 5.73 & 7.27 \\
\hline
\end{tabular}

substances can be attributed to reduction in the quanțity of insoluble phosphates of iron and aluminum Suresh and Mathur (1988).

The potassium content (Table $V$ ) of soil crust and soil below the crust varied significantly due to different treatment receiving FYM maize residue, coir pith and potassium. The increase in potassium can be attributed to release from clay minerals and contribution of potassium from organic residues. Increase in potassium due to organic residue application was also observed by Subramaniam and Kumaraswamy (1989).

\section{Sesquioxides, Iron and Dispersion of Soil Crust and Soil Below Crust}

\section{Sesquioxides}

The sesquioxides content of crust was higher than soil below the crust (Table VI). The increase in sesquioxides can be attributed to increased amount of finer fractions in crust and the coatings of sesquioxides on other soil particles during in crust formation. Aubert (1963) opined that the ferrolytic crust of tropical region consists 
of oxides and hydroxides of $\mathrm{Fe}, \mathrm{Al}$ and $\mathrm{Mn}$ with varying degree of kaolinite and quartz. Ranganatha (1976) observed higher sesquioxide in soil crust than soil below crust. The variation in sesquioxide of soii crust can be attirubted to variation in finer particles of soil crust.

\section{Iron content}

The iron content (Table VI) of the crust was higher than soil below the crust. Russel (1961) found that hardening of soil was caused by colloidal iron oxides.

Table VI Sesquioxides, Iron and dispersion ratio of soil crust and soil below it

\begin{tabular}{|l|c|c|c|c|c|c|}
\hline \multicolumn{1}{|c|}{ Treatments } & \multicolumn{2}{c|}{$\begin{array}{c}\text { Sesquioxides } \\
(\%)\end{array}$} & \multicolumn{2}{c|}{$\begin{array}{c}\text { Iron } \\
(\%)\end{array}$} & \multicolumn{2}{c|}{$\begin{array}{c}\text { Despersion } \\
\text { ratio }\end{array}$} \\
\hline & $\begin{array}{c}\text { Soil } \\
\text { crust }\end{array}$ & $\begin{array}{c}\text { Soil } \\
\text { below } \\
\text { crust }\end{array}$ & $\begin{array}{c}\text { Soil } \\
\text { crust }\end{array}$ & $\begin{array}{c}\text { Soil } \\
\text { below } \\
\text { crust }\end{array}$ & $\begin{array}{c}\text { Soil } \\
\text { crust }\end{array}$ & $\begin{array}{c}\text { Soil } \\
\text { below } \\
\text { crust }\end{array}$ \\
\hline T1FYM & 1.18 & 1.25 & 211.68 & 215.60 & 88.53 & 90.66 \\
\hline T2Maize residue & 1.25 & 1.30 & 227.36 & 239.12 & 91.69 & 92.89 \\
\hline T3Coirpith & 0.92 & 0.98 & 184.24 & 199.92 & 88.12 & 88.44 \\
\hline T4Groundnuthusk & 1.03 & 1.10 & 199.92 & 211.68 & 93.34 & 90.66 \\
\hline T5Pressmud & 0.92 & 0.97 & 184.24 & 196.00 & 8.12 & 88.56 \\
\hline T6 Potassium & 0.86 & 0.89 & 166.80 & 164.24 & 82.96 & 83.38 \\
\hline T7Control & 0.85 & 0.89 & 166.80 & 172.14 & 82.96 & 83.38 \\
\hline Ftest & $*$ & $*$ & $*$ & $*$ & $*$ & $*$ \\
\hline CDat5\% & 0.07 & 0.09 & 20.01 & 21.05 & 2.34 & 2.31 \\
\hline
\end{tabular}

\section{Dispersion ratio}

The data on dispersion ratio (Table VI) indicate that crusts had higher dispersion ratio than soil below crust. This may be due to presence of higher colloidal particles in the crust. Zaslavasky ef al. (1980) reported that the dispersed finer fractions of soil forms crust. The higher dispersion ratio can be attributed to the presence of finer particles in crust which are susceptible for dispersion. 


\section{References}

1. AUBERT, G., 1963, SOIISCI., M: 235-242.

2. BAVER, LD, GARDNER, W.H. AND GARDNER, W.R., 1972, SoU Physics. Fourth Edition, John Wiley and Sons, Inc., New York.

3. GUPTA, S.C., SCHNEIDER, E.C., LARSON, W.E.AND HADUS, A., 1987, Soil Sci. Americo J., 207-212.

4. HAZRA, C.R., 1986, J. Indian SOC. Soil Sci., 34:396-400.

5. PANDEY, S.P., HARISHANKAR AND SHARMA, V.K., 1985, J. Indian SOC. Soil Sci, 33: 179 181.

6. PARVATHAPPA, H.C., KANTHARAs, M.L AND HEGDE, B.R., 1988, Proc. inter. Conf. On Dry land Forming, Amarillo, Texas, USA, Part VI, 461- 463.

7. RANGANATHA. B.R.. 1976, M.Sc..(Agri.) Thesis. University of Agricultrual Sciences, Bangalore.

8. RUSSEL, E.W., 1961, Soil conditions and plant growth $9^{\text {th }}$ ed. Longmans Green and Co., London.

9. SUBRAMANIAN, K.S., AND KUMARSWAMY, K., 1989. J. Indian Soc. Soil Sci.. 37:171-173.

10. SURESH LAL AND MATHUR. B.S.. 1988. J.Indian Soc. SoilScL 36:113-119.

11. UNGER, P.W. AND MCCALLA, T.M.. 1980, Conservation tillage systems. Adv. Agron., 33:2-53.

12. ZASLAVASKY, D., ROZENBERG, L. AND SHAVIV, A., 1980, Engineering comprehensive report, 1975,1979, Pub. No. 310, Haifa, Israel. 